\title{
Styring av vitenskap på ville veier
}

\author{
«Den Gud gir et embete, gir han også forstand,» står det i artikkelen fra 1974 som gjengis her. \\ Det pekes også på at så enkelt er det ikke. På en løsningsorientert måte kritiseres både selve \\ utnevningen av professorer og utøvelsen av yrket. Fortsatt aktuelt?
}

\begin{abstract}
I 1950-årene ble syndromet professorose beskrevet: Rykker man opp til toppstilling blir det så mange andre oppgaver, og professoren blir betraktet som et orakel innen alle mulige felt. Men faget som brakte vedkommende til topps blir grundig forsømt, så der blir han eller hun nærmest ubrukelig. 20 år senere kom Rolf Seljelid med et innspill i debatten om hvilke arbeidsoppgaver en person i toppstilling skulle utføre og hvilke man trygt kunne overlate til andre. Her kommer han med en dyster beskrivelse av tilstanden i norsk forskningsverden. Det gjelder både den toppkompetente forskers arbeidsoppgaver og hvordan vedkommende skal utøve akademisk lederskap. Med drepende ironi avslører han et system som fungerer dårlig og viser hvordan enkeltpersoners inkompetanse og arbeidsoppgaver utenfor sitt eget fag skaper stadig problemer.
\end{abstract}

Rolf Seljelid (f. 1934) tok medisinsk embetseksamen ved Universitetet i Bergen i 1959. Etter noen års spesialistutdanning i patologi ved Radiumhospitalet i Oslo, reiste han til Sverige der han i flere år drev eksperimentell forskning. Han tok doktorgrad ved Karolinska Institutet i Stockholm i 1966. Siden var han gjesteforsker i et år i USA, og fra 1971 ble han professor i patologi ved Universitetet i Tromsø. Etter sine utenlandsår i store, internasjonale forskningsmiljøer kom Seljelid som et friskt pust tilbake til Norge. I tillegg til å være en anerkjent internasjonal forsker stilte han flere diagnoser på norsk forsknings hensyknende tilværelse. Det manifesterte seg i artikkelen Forskning og akademisk lederskap, som ble trykt i tidsskriftet Samtiden i 1974. Valg av tidsskrift er også et uttrykk for Seljelids allsidighet og samfunnsengasjement. Ved siden av å inneha en rekke akademiske og andre verv i norsk forskning og en lang vitenskapelig merittliste har han litterære og kunstneriske interesser og har gitt ut flere bøker.

Ut ifra prinsippet «rett behandling krever rett diagnose», er det opp til leserne å vurdere hva som har vært gjort for å bedre akademisk lederskap og forskningens organisering i de snart fire tiårene som har gått siden. Er det blitt bedre eller verre? Min egen oppfatning er at det kunne ikke bli verre enn det var den gangen. To viktige moment manglet imidlertid i Seljelids opprinnelige analyse. Det ene er positivt, mens det andre er negativt: Kvinnenes inntog i forskningen har vært en viktig fornyelse, mens overdreven byråkratisering og kontroll kan lamme selv de beste miljøene. Men i det store og det hele tror jeg vi skal være fornøyde med de store løft som har vært gjort. Vitenskapen blomstrer som aldri før, og skulle noen være i tvil, så er det bare å lese om igjen Seljelids skarpsindige analyse fra den gangen. Likevel er jeg bekymret over at ingen har tatt opp prosjektet med trillografering av kveruloplaster. Det er fortsatt ledig for en ambisiøs stipendiat.

\section{Ole Didrik Lærum}

ole.laerum@gades.uib.no

Ole Didrik Lærum er professor (adj.) ved Københavns og professor emeritus ved Universitetet i Bergen.

\section{Forskning og akademisk lederskap}

Samtiden 1974; nr. 4: 215-23.

Det var en gang da universitetet rommet en liten forfinet åndselite, og professorer var elskverdige eldre herrer som visste mer og mer om mindre og mindre. Deres materielle ressurser var uhyre enkle. Omkring seg hadde de en liten skare av sterkt motiverte, strengt utvalgte adepter, studentene var få, vitenskapen hellig. I sin virksomhet som akademikere hadde de lite med samfunnet omkring å bestille, og fremfor alt: Ingen utenfor kunne engang tenke en så formastelig tanke som å legge seg opp i hva professorene foretok seg inne i søylehallene.

Siden den gang har universiteter og høyskoler forandret seg til kandidatfabrikker, instituttene er blitt arbeidsplasser for hundrevis av mennesker av de forskjelligste kategorier, en akademiker i toppstilling har funksjoner meget á la sjefen i et middels stort firma, millioner av kroner disponeres, superavansert utstyr må tas vare på og brukes. Forskningsresultatene er ikke lenger fjerne ekko av et ritual for de få innvidde, men profane practicalities som opptar tusenvis av mennesker foran TVapparatene og bak avisene.

Men likevel, likevel er det formelle apparat som omgir disse toppakademikere i alt vesentlig det samme som en gang ble tilrettelagt deres forgjengere av distré ånds- mennesker. Alt, nesten alt er som før - bare ikke hva det skal tjene til.

\section{Fotnote:}

Den Gud gir et embete, gir han også forstand, heter det i et gammelt ordspråk. Med en svak omskrivning kan man kanskje si at den som av Staten i dag fär et professorat ved et av våre universiteter, han vil også på et eller annet vis finne en mulighet til å oppfylle sine plikter og utføre sitt mangfoldige arbeid. Så enkelt er det bare ikke. Akademiske ledere velges etter prinsipper som hører hjemme i en fjern fortid, og mange av dem arbeider under forhold som gjør det umulig for dem å yte sitt beste. - Rolf 
Seljelid (f. 1934) er siden 1971 professor $i$ medisin (morfologi) ved Universitetet $i$ Tromsø. Tidligere var han knyttet til Det Norske Radiumhospital og til Karolinska Institutet i Stockholm, der han også tok sin doktorgrad. Han har tidligere behandlet emnet for denne artikkelen $i$ «Nordisk medisin» (88, mars 1973).

Selve leder-funksjonen i det akademiske samfunn, utdannelse, utvelgelse, utøvelse av lederskap, har ikke egentlig vært revidert siden de dager da salig Daae ville be om avskjed fordi den første real-artianer fikk innpass på universitetet. Utdannelsen av våre toppfolk er fremdeles tilpasset et livslangt virke i ufarlig Geisteswissenschaft, mens kravene i dag til en akademisk toppleder ofte spenner over et bredt register av høyst jordisk art. Utvelgelsesprosessen er en levning fra en tid da få drev forskning (men god forskning), da alt vesentlig som kunne sies om en mann kom frem i hans vitenskapelige publikasjoner. Utøvelsen av lederskap hemmes av en tradisjon i amatørmessighet og naivt dimensjonerte administrative ordninger med en air av fjærpenner og skrapende notater om utgift til nytt sommerfuglnett - ikke så sjarmerende lenger i 1974 for de som tynes av mangel på effektivitet $\mathrm{og}$ fornuftige arbeidsordninger.

\section{A. Utvelgelse av ledere}

For å få litt relieff i det hele, skal vi først se på den nåværende prosedyre ved valg av akademiske ledere. Eksemplene er tatt fra mitt eget fag, medisin, men ordningene er $i$ alt vesentlig de samme $i$ alle fag. Jeg velger å se det ut fra synsvinkelen forskning, fordi det antagelig er den mest typiske aktivitet ved høyskoler, universiteter og institutter. Jeg vil tro man uten vanskelighet ville kunne anlegge andre synsvinkler og komme til omtrent de samme resultater. De fleste vil kjenne hovedtrekkene fra før.

Professorater og dosenturer utlyses med annonse. Det søkes skriftlig, og søknadsfristen er ofte noen få uker. Søknadene er individuelt utformet: Søkerne beskriver sin utdannelse og vedlegger eksamenspapirer, attester og liste over vitenskapelige publikasjoner. Disse vedlegges eller ettersendes (fristen er tre måneder). Deretter nedsetter fakultetet en sakkyndig komité, ofte tre personer, som skal uttale seg individuelt eller avgi samlet innstilling. De har følgende dokumenter å bygge på: de innsendte papirer fra søkerne, universitetets reglement for ansettelser og eventuelle særinstrukser for stillingen. Etter flere måneder kommer de sakkyndiges uttalelse. Dersom de uttaler seg individuelt, foreligger ikke sjelden meget divergerende syn på rangeringen av søkerne. Dersom de uttaler seg som komité, er den innbyrdes uenighet oftest mindre. Etterat de sakkyndiges uttalelser er blitt kjent, kommer en periode da alle er i opprør.
Noen av søkerne mener seg urettferdig behandlet og protesterer, eller er stumt rasende. Nærstående personer, f. eks. avdelingens sjef, dersom stillingen er underordnet eller sideordnet, kan ha håpet på et annet resultat. Han er da også rasende og arbeider for å få fakultetet til å oppnevne en ny komité som skal vurdere de sakkyndiges vurdering (les: omgjøre den). De sakkyndige er nedtrykte, bitre, rasende eller stoisk rolige alt ettersom. Individuelle medlemmer av fakultetet blir lett trukket inn i de emosjonelle kraftfelt omkring de forskjellige standpunkter. Fakultetet som helhet henviser til de sakkyndige som (de som egentlig) har hatt avgjørelsen så langt, og de sakkyndige henviser til fakultetet. Etter en tid må fakultetet ta en bestemmelse. Dersom de sakkyndige har vært uenige, foretar fakultetet et reelt valg. Dersom de sakkyndige har vært enige, forandrer fakultetet sjelden deres rangering. Saken går deretter til kollegiet, som sjelden forandrer noe. Så går saken til departementet, som enda sjeldnere forandrer noe, så til Kongen, som uhyre sjeldent forandrer noe.

Hva har nå skjedd? Man har fått ansatt en person i stillingen - ofte omtrent et år etter at stillingen ble lyst ledig. Mange vondord har falt, flere personer er blitt uvenner for kortere eller lengere tid, paranoiaen blomstrer. Nå kunne jo denne betydelige investering $\mathrm{i}$ tid, arbeidskraft og adrenalin være akseptabel dersom systemet ufeilbarlig frembrakte den beste kandidat. Så er neppe tilfellet. Hovedankepunktene er:

I. Systemet er bare tilsynelatende grundig. I virkeligheten er det snarere tungrodd. Jeg tror man som regel kunne gjøre et like bra valg etter en times diskusjon.

2. Systemet er bare tilsynelatende saklig. Allerede i utvelgelsen av de sakkyndige personer har man ofte gjort et valg i favør av noen kandidater og i disfavør av andre. Den instruks som gjelder for stillingen kan være formulert slik at den favoriserer, ja nærmest utpeker en søker («bare hattenummeret manglet»). De sakkyndige kan umulig ha faglig innsikt i alle søkernes vitenskap. Det er i våre dager selv innen et begrenset fag så mange undergrupperinger at det praktisk talt ikke finnes sjanse for at et sakkyndig utvalg skal forstå seg på alt. De er således bare tilsynelatende sakkyndige. De sakkyndige kan umulig ta den tid det skulle gå med til virkelig å sette seg inn i sakene (flere tusen sider, pluss bakgrunnsstoff), samtidig som de er nødt til å utføre et krevende yrke.

De sakkyndige kan enten velge å være «saklige», dvs. bare ta hensyn til skriftlig dokumenterte fakta - de kan da komme til resultater som er helt uforenlige med sunn fornuft - eller de kan velge å være «usak- lige», dvs. ta hensyn til hva folk sier etc., og da kan de begå rene justismord.

3. Systemet er ikke i samsvar med oppgaven, dvs. å finne en dyktig person til en ledende akademisk stilling. Det legges altfor stor vekt på finsiktning av skriftlige publikasjoner. Det er altfor lite anledning til å vurdere søkernes lederegenskaper, undervisningsevner, samarbeidsevne og alminnelige faglige kunnskaper.

\section{Det er ingen klar ansvarsdeling i pro-} sessen. Skillet mellom sakkyndige og decision-makers er meget uskarpt. Dette skaper rom for manipulering, uro, paranoia.

Det er for lettvint å kritisere et system uten å ha noe annet å foreslå. Jeg vil absolutt ikke påstå at jeg har løsninger på de problemer som er beskrevet ovenfor. Men jeg vil anta at man ville komme et stykke ved å erkjenne at der er problemer. Av konkrete forandringer som kunne overveies, ville være: $a$. klarere skille mellom sakkyndige og decision-makers. $b$. klarere mandat for de sakkyndige. $c$. større vekt på vitenskapelig utdannelse. $d$. større vekt på dokumenterte lederevner, evne til å skape et godt miljø, samarbeidsevne.

I praksis kunne man kanskje overveie noe av dette: Fakultetet eller tilsvarende oppnevner en liten «decision-making committee», som i realiteten får ansvar og myndighet til å utpeke den rette person blant søkerne. Medlemmene av komiteen utpekes før søknadene er innkommet og arbeider på basis av instruks for stillingen utarbeidet av fakultetet. Komitéen (3 personer?) må være sammensatt slik at rene fremmed-transplantasjoner unngås (således bør avdelingens sjef være med dersom den nye stilling er sideordnet eller underordnet) og slik at faren for grovere nepotismer reduseres (ett medlem fra annet universitet). Det bør være større adgang til kallelse (som må godkjennes i fakultetet). Det bør være veto-rett innen komitéen. Komitéen tilkaller sakkyndige etter eget behov, studerer disses uttalelser (skriftlige og muntlige), eksaminerer de sakkyndige. De innhenter opplysninger om de mest aktuelle søkeres vitenskapelige sosial-anamnese, innkaller og konfererer med de mest aktuelle søkerne. Komitéen kommer til en enstemmig uttalelse som så bare i rene unntakstilfelle må forandres av fakultetet, kollegium osv.

Dette er bare en skisse. Jeg har hverken nok erfaring eller innsikt til å gå lenger. Men allerede denne lille antydning rommer synes jeg - vesentlige fordeler fremfor den nåværende ordning.

\section{B. Utdannelse av ledere}

Hva slags utdannelse har våre akademiske ledere idag? 
La oss se på en typisk, vellykket medisinsk karriere: Cand. med. X gjør seg ferdig med turnustiden. Han skriver en kasuistikk mens dette pågår. Han søker og får (delvis på grunn av sin kasuistikk, som viser «interesse for faget») stilling som assistent på fagologisk avdeling. Her er det ikke flere rutinemessige forpliktelser enn at han har tid til å forske. Dette initieres ved at professor i fagologi sier: «Burde ikke du, X, se litt på kveruloplastene»? Etter denne malmfulle uttalelse drar professoren seg tilbake til sine administrative oppgaver. $\mathrm{X}$ er lykkelig i mange dager, begynner så å se på kveruloplastene.

Det viser seg imidlertid at mange har sett på dem før, men heldigvis ikke i Norge. $X$ lærer seg nå av dosent $Y$ å trillografere. Han trillograferer deretter kveruloplaster i noen år. Det meste av hans «fritid»(?) går med til dette, han har kone og tre barn, kjører legevakt for å få endene til å møtes. Etter fem år har han et «materiale». På dette tidspunkt dukker atter professor i fagologi opp. Han sier: «Burde ikke du, X, skrive dette sammen»? Han begir seg deretter med synlig stolt gange tilbake til sine administrative plikter. X er henrykt. Borte er bekymringer om hus og avdrag, borte er ubehagelige fornemmelser rundt hjertet, borte er sterkt undertrykte negative følelser for den avspaserende professor. X skriver sammen, «leverer», «får».

På doktormiddagen sier alle at dette er fantastisk. Professor i fagologi tilstår at han ikke forstår noe av det hele. Alle synes det er makeløst beskjedent sagt.

Så søker X dosentur. Han støttes av professor, utvikler paranoia, er noe skuffet over de sakkyndige, får dosenturet. - Noen år går. Han driver stadig med trillografi (men det er ikke så morsomt som før, pussig nok), tas med i et par komitéer (nyter det), instruerer cand. med. $\mathrm{Z}$ i trillografi, underviser (naturligvis uten at noen legger seg opp i det), skriver i Tidsskrift for Den norske lægeforening om trillografiens betydning innen medisinen, får $15000 \mathrm{kr}$ av Forskningsrådet til utstyr for automatisk trillografi.

Nå blir det ledig et professorat i fagologi i nabobyen. X søker. Han støttes stadig av sin professor, utvikler booster-paranoia, er rasende over de sakkyndige, protesterer, noen trekker seg, han får jobben.

En fullstendig forandring inntrer i X's liv. Han overtar administrasjonen av sin avdeling, sitter i tallrike komitéer, blir medlem av forskningsrådet og legger trillografien på hylla fordi de administrative plikter blir så tyngende. Han prøver imidlertid å stimulere yngre forskere, f. eks. ved å si: «Hør, $\beta$, burde ikke du se litt på snidoforene»? Han merker seg $\neg$ ikke uten glede - at $\beta$ blir himmelfallen over denne uttalelse.

Hva slags yrkesmenneske er X blitt? Han har dårlig vitenskapelig utdannelse (har arbeidet på en eller i høyden to avdelinger eller institutter, har aldri hatt systematisk opplæring i forskning) og han er derfor en slett vitenskapelig veileder. På grunn av at viktige år ble brukt til trillografi har han middelmådig praktisk kyndighet i sitt fag. Overlegen på fylkessykehuset er bedre. X er havnet $i$ en stilling med store administrative plikter og forvalter en ikke ringe del av vårt nasjonalprodukt, men han har ingen administrativ utdannelse (og tror derfor dette er unødvendig). Han har en stilling som på grunn av prestisjen hindrer ham effektivt i å bedre på manglene.

Beskrivelsen er satt på spissen (for sikkerhets skyld bør dette sies), men den er ikke fjernere fra virkeligheten enn at den ligner. Jeg tror at særlig de som sitter i ledende stillinger etter å ha vært igjennom prosessen $A B$ villig vil innrømme manglene ved systemet, både fordi de daglig merker - eller bør merke - insuffisiensen i sin utdannelse, og fordi de ofte er vitne til meningsløsheter ved sakkyndige uttalelser og ansettelser.

Hva kan vi gjøre for å forbedre utdannelsen av akademiske ledere? Igjen drister jeg meg til å komme med noen få konkrete forslag, uten å tro at dette er annet enn antydninger av mulige tiltak:

a. gi de som sikter på akademiske lederstil-

linger, bredere og mer systematisk vitenskapelig utdannelse

b. stimulere og honorere kontakt med andre miljøer

c. revurdere leder-rollen. Hvem skal bla

i papirene og hvem skal forbli i faget?

\section{Utøvelsen}

Hva gjør våre akademiske ledere - hvordan er deres dager?

Av «Utredning om forskning og høyere utdanning» (Norges Almenvitenskapelige Forskningsråd 1973.3) fremgår at akademikere i høyere stillinger ved Universitetet i Oslo av en arbeidsuke på gjennomsnittlig 53 timer (1971) hadde 17 timer for forskning, dvs. omtrent 30 prosent (tabell 1, s. 116). Dette inkluderer også bakgrunnslesning etc. Med andre ord: våre toppfolk har mellom 2 og 3 timer pr. dag til forskning i en uke som altså ikke er 40-timers. (En telling fra Troms nylig viser enda lengre arbeidsuke og forholdsvis mindre tid til forskning.)

Ellers går tiden med til undervisning og supervisjon (20 t), administrasjon, ekstern service og andre aktiviteter (16 t). Disse oppgaver er obligatoriske. Forskningen er ikke det. Dersom arbeidsuken ble redusert til det som er vanlig for de fleste i samfunnet, vedder jeg ganske mye på at det ville være forskningen som gikk ut. Den kommer sist, og må utføres på toppen av en vanlig arbeidsuke. Dette gjelder våre toppfolk, våre profesjonister.

Ordningen får perspektiv hvis vi transponerer den til en annen yrkesgruppe.

La oss tenke på en musiker, en pianist. Han utdanner seg, går musikkskolen, spiller privat, kommer inn på akademiet, gjør fremgang, debuterer i Aulaen (= «doktorgrad»), gir konserter (= «publiserer»), blir anerkjent, kan kanskje til og med leve av sitt yrke (= «får stilling») og så, så tvinger systemet ham til å bli impressario! Alle tar det som en selvfølge at han fra nå av skal arrangere konserter for yngre musikere, (ved siden av naturligvis å ordne med notene og reparere pianoet), departementet gir hint om at minst 50 prosent av arbeidstiden skal anvendes til slik aktivitet, «det er forresten ikke en selvfølge at det ikke er 100 prosent.» Musikere i $40-50$ års-alderen treffer hverandre og spør: «Får du spilt noe, da?» «Nei, du vet det blir ikke stort når all administrasjonen er unnagjort. Denne uken har jeg ikke rørt klaveret».

Alle ville være enige om at dette var grotesk. Et system som forlangte at Jan Henrik Kayser eller Liv Glaser skulle administrere andres konserter, og ikke nødvendigvis spille selv, ville bli forkastet til og med i departementene. Men med vitenskapsmenn går det an! Ingen synes tydeligvis det er en rystende mangel på økonomisk sans når en professor gjennomsnittlig bruker 4 eller 6 timer pr. dag til å telefonere om priser, skrive på maskin med en finger, studere regnskaper, delta i byggemøter, ut/forarbeide budsjetter, søke om penger, antichambrere i forskningsrådene, bestemme hva slags nøkkelsystem man skal ha i huset, fastlegge vaktmesterens ferie osv. osv. Noe av dette er igjen overdrivelse, og noe av det er selvforskyldt. Men det faktum gjenstår at vårt system tillater eller snarere forlanger at høyt kvalifiserte mennesker, som har brukt 30 år eller mer av sitt liv til å nå det faglige nivå de befinner seg på og burde være mer produktive enn noensinne, skal nedlegge eller nedtrappe sitt faglige virke og drive såkalt administrasjon. (Jeg sier såkalt, for her er de fleste av dem rene amatører, og til og med ganske ubegavede amatører.) Det virker nesten skremmende at en rekke mennesker i ledende posisjoner ikke skjønner at vitenskapsmenn likesåvel som musikere og andre i kreativt arbeid trenger arbeidsro, anledning til konsentrasjon, muligheter for å arbeide på $\sin$ måte.

Jeg hører innvendingene. Hvordan skulle det gå hvis alle (den klassiske innvending) bare skulle forske, hvem skulle da drive 
undervisning, befolke komitéene, sitte i Forskningsråd etc.?

\section{Jeg skal forsøke å svare på dette.}

I. Først må man bestemme om man vil ha forskning overhodet. Samfunnet (Stortinget?) må bestemme dette, og også si noe om hva slags forskning man ønsker.

Noe. Hva vil vi ha rede på? Hva er samfunnet villig til å betale for? Skal vi finne ny behandling for kreft, utdype forståelsen av vår nasjonale egenart, se på de praktiske konsekvenser av en lov, bestemme universets alder, lete etter olje?

Naturligvis er dette vanskelige overveielser og berører noe så komplekst som vår sivilisasjon; ingen kan vente presise formuleringer eller endelige prioriteringer. Men noe må samfunnet kunne si om dette, og samfunnet må være klar over sitt ansvar for å ta denne bestemmelse.

Kanskje vil samfunnet si at vi vet nok: «La oss $i$ et lite land som Norge konsentrere oss om å anvende det vi vet, vi har ikke midler store nok og ikke tilvekst av mennesker stor nok til å drive forskning.» La gå med at en del forskning ikke kan drives andre steder (eks. landbruk, språk, jus) og at dette antagelig ville få katastrofale følger for vår kultur, for vår generelle faglige standard etc. Men likevel; dette måtte vi langt på vei godta dersom samfunnet så bestemte.

Men var vi først enige om å ha forskning som målsetting, måtte vi også ville midlene. De er av 3 slag: begavelse, penger, tid. Det er bra med begavet folk her på berget. Samfunnet tildeler i dag rimelig med penger til forskningen (= utstyr, drift, reiser, litteratur etc.). Men ingen ser til at forskerne har tid og arbeidsforhold som samfunnet er tjent med! Det er helt urealistisk å tro at en person med 2 timer dagen til disposisjon vil kunne finne ut noe av betydning om $\mathrm{f}$. eks. kreft. Hvilket igjen betyr at dersom samfunnet virkelig ønsker at vårt land skal delta i kreftforskning, må et passende antall topputdannede og nøye utvalgte personer avlastes i tilstrekkelig grad til å gjøre jobben. Legger man undervisning, komitéarbeid og administrasjon på dem i en slik grad at det går katastrofalt ut over forskningen, så har man sagt: Vi vil, men vi vil ikke. Det er rent økonomisk vanstell å holde forskere gående på $1 / 4$ maskin. Det hjelper ikke at de har yngre kolleger (sml. pianisten). Det hjelper ikke at det står utstyr for millioner til deres disposisjon og at de har ordnede økonomiske forhold hjemme.

II. Rimelig undervisning er bra for de fleste forskere. Det har vist seg mange ganger, mange steder, at forskere isolert fra studentene har tendens til å stagnere. Mengden av undervisning må imidlertid, som ovenfor beskrevet, tilpasses det man for øvrig vil at de samme personer skal gjøre. Det kan være et spørsmål om ikke tiden er inne til en viss differensiering mellom undervisere og forskere. Her bør det utvelges på basis av personers lyst og evner, og samfunnets behov igjen. Økonomisk og annen stimulering kan overveies. (Forskning er oftest så morsomt at den under like vilkår ellers ofte vil beseire undervisning i kamp om interesse.) Igjen:

Besvarer man dette forslag med å påpeke at samfunnet ikke har råd til å belaste forskerne mindre, så har man sagt «vi vil ikke ha god forskning», på en annen måte. Det er etter min mening ikke tvil om at minst 50 prosent av forskningen her i landet er helt medioker og kunne vært sløyfet. At anneneller tredjeklasses forskning i noen tilfelle kan tjene undervisningsformål er en annen sak. Men som regel er heller ikke dette tilfelle. Vårt system er slik at vi tvinges til å produsere selv om forholdene bare ligger til rette for publikasjon av alminneligheter.

III. Mon ikke tiden også er kommet til å skjelne mer mellom administratorer og forskere? En god begynnelse ville kanskje være å bruke spesialkategorier av administrativt personale til å ivareta den daglige administrasjon på alle plan. Jeg har tro på at det er fullt mulig for en person på kandidatplanet å administrere et institutt, avdeling eller lignende, hvis han eller hun er dertil utdannet. Forutsetningene må være to: At man utdanner dem til å se som deres oppgave å lede institutt eller avdeling slik det tjener disse (og ikke eventuelle egne målsettinger), og at man har en kontrollerende instans, et lite råd eller styre, eller en enkeltperson valgt/utgått blant forskerne, som kan representere den øverste, demokratiske myndighet.

Jeg har truffet noen få slike gode forskningsadministratorer. Særlig husker jeg daglig leder ved Trudeau-instituttet i USA. Han sa: «Jeg kom hit fra næringslivet, og startet med å stille det spørsmål enhver administrator ny $i$ en bedrift vil stille: Hva er bedriftens sluttprodukt? Når dette spørsmål er besvart, får man straks en retningslinje for alle administrative tiltak, og man får holdepunkter for prioritering: Alt som tjener fremstilling av sluttproduktet (i dette tilfelle $=$ forskning) er bra, alt som ikke tjener det, er uvesentlig eller skadelig».

Av og til forekommer det nok at en struktur har flere sluttprodukter som kan skape konflikt, f. eks. forskning, undervisning, service, men dette er etter min erfaring sjelden. Problemet er nesten alltid å bekjempe uvesentlige målsettinger: administrasjon for dens egen skyld, snedig uttenkte systemer som ikke er avmålt etter sluttproduktet, utenforliggende hensyn og personlig smak, klåfingrethet, misunnelse.

Jeg tror absolutt ikke at man helt kan avskaffe administrativt arbeid for forskerne. Noen valg kan bare de ta, noen bestemmelser er kun de kompetente til å gjøre. De må definere hva som er instituttets, avdelingens siktemål, de må ta beslutninger i prinsipielle spørsmål og til syvende og sist ha det avgjørende ord i en sak. Men det er også helt klart at en masse administrasjon bør kunne gjøres av andre, at utredningsarbeid og utføring av beslutninger i stor utstrekning kan overføres til andre. Husk hele tiden: Forskere er ikke mer enn gjennomsnittlig kompetente til å ta hånd om de fleste administrative saker de i dag behandler.

Mye av det som er sagt ovenfor, gjelder også sentrale organer, som forskningsråd o.l. Det er viktigere jo høyere opp man kommer at alle forstår at administrasjon ikke har verdi i seg selv, men kun sluttproduktet, forskningen.

\section{Konklusjon}

Hele vår vestlige sivilisasjon bygger på vitenskap. Ikke bare har vitenskapen gitt praktiske holdepunkter, konkrete forbedringer av vårt liv, men danner på godt og ondt grunnlaget for vår kultur. Det vil derfor antagelig være liten uenighet om at vi må ha forskning. Vi må se i øynene at forskning er en nødvendig del av vårt samfunnsliv. Vi må finne ut hvor mye som skal satses på forskning $\mathrm{i}$ konkurranse med andre samfunnsaktiviteter, og så må forholdene legges til rette for å få noe ordentlig igjen for de ressurser som satses. Forskning må ikke ses på som en belønning en viss type personer skal få når de om kvelden har gjort seg ferdig med andre, trivielle sysler.

Forskningen er i dag blitt så krevende (metoder, kunnskapsmasse) at vi trenger profesjonister. La oss legge til rette forholdene for utdannelse og passende utvelgelse av slike. Samfunnet må da kunne vente førsteklasses arbeid fra dem. Slik det nå er, kan dette ikke ventes. Bare unntagelsesvis p.g.a. umenneskelig arbeidsinnsats eller noe annet unormalt vil dette inntreffe.

Universiteters og institutters oppgave og plass i samfunnet, og ikke minst dimensjonene på tiltakene, har forandret seg meget siden våre nåværende administrative metoder ble fastlagt. Derfor bør vi nå fordomsfritt og med oppfinnsomhet revurdere disse metoder. Det retningsgivende prinsipp må være: definér sluttproduktet.

Rolf Seljelid 